\title{
Roots of Modernization: Educational Reform in Iowa at the Turn of the Century
}

\author{
KEACH JOHNSON
}

THE ROOTS of elementary and secondary education in Iowa go back to the common schools of the nineteenth century, but it was not until the turn of the century that the state's public school system began to take on its present structure and meaning. The turn of the century is one of the great watersheds in American history, a tumultuous time of transition from the agrarian society of the past to the industrial society of the present. The Progressive movement, which emerged at that time, was largely a response to the demands of industrialism. Progressives pressed for a wide range of social reforms to meet those demands.

In no area of social concern was the response to industrialism more pronounced than in education, as Iowans and other Americans awakened to the need for better schools and took steps to meet that need. Progressive educators, recognizing that schools were social institutions that must change as society changed, instituted a series of responses to industrialism. Iowans provided better training for teachers, built and maintained more adequate facilities, systematized and standardized curricula and procedures, and consolidated rural schools. Teachers themselves organized into a professional state association that developed a legislative program and lobbied in the General Assembly for its adoption. These responses combined to give rise to the public school system that has survived throughout the twentieth century.

THE ANNALS OF IOWA 50 (Spring 1991). (CThe State Historical Society of Iowa, 1991. 
THE TURN OF THE CENTURY was a time of vibrant growth in Iowa, particularly in the western and northwestern parts of the state, which were largely settled in the last third of the nineteenth century. Growth and prosperity provided the incentives, means, and rationale for better schools. The "constant addition of vigorous, enterprising blood" in Pocahontas County, declared Superintendent U. S. Vance in 1902, created a popular demand for better schools, leading to the construction of many "modern" rural school buildings, the weeding out of incompetent school officials, the enrollment of a large number "of our best young men and women" at Iowa State Normal School in preparation to teach, and the establishment of high schools in all of the towns in the county. ${ }^{1}$

Growth and prosperity also led to public demand for better schools in Sioux County on the South Dakota border northwest of Pocahontas County. The population of Sioux County grew from 18 in 1867 to 23,337 in 1900 with corresponding growth in the economy and in schools. The number of schools, in fact, grew too rapidly in the judgment of Superintendent E. D. Brown. The county's greatest educational problem, said Brown, was the difficulty of finding enough qualified teachers to meet the "excessive" demand for teachers resulting from too many small schools; there were 172 rural schools and 11 independent town school districts with 76 teachers in Sioux County in 1900. "People will be moved more and more in this county to try consolidation," Brown predicted. "Rich farm lands, prosperity, and a young, inexperienced teaching force will hasten the elimination of small, weak districts." Consolidation would be led, Brown believed, by men "of easy means" who were dissatisfied with the "meager" educational advantages of the existing school system and were able and willing to pay for better schools. $^{2}$

Closely related to settlement and growth were two other major causes of economic and social change, industrialization

1. Iowa Department of Public Instruction (hereafter cited as IaDPI), Report (1902), 328-29. These reports were published separately and reprinted in Iowa Legislative Documents. Superintendents referred to in the text are county superintendents unless designated otherwise.

2. Ibid., 67, 334-35. 
and urbanization. Iowa remained predominantly agrarian in 1900 , but Iowans were busily engaged in building a diverse economy based on manufacturing and commerce as well as agriculture. The number of manufacturing establishments in Iowa rose from 6,921 in 1880 to 14,819 in 1900 , while the value of the state's manufactured products more than doubled in the same years. By 1900 Iowa ranked seventeenth nationally in value of manufactured products. Industrialization bred urbanization; manufacturing in Iowa as elsewhere was largely an urban enterprise. The number of cities and towns in Iowa with ten thousand or more inhabitants rose from seven in 1880 to seventeen in 1909. In 1910 Iowans residing in towns of twentyfive hundred or more constituted 31 percent of the state's population. ${ }^{3}$

The exodus of people from the country to the city devastated many rural school districts, particularly in the older, more settled parts of the state. The rural population had declined in some parts of Iowa to the point that, as State Superintendent Barrett reported in 1899,53 percent of the independent districts and 79 percent of the township subdistricts in the state had an average daily attendance of fewer than twenty pupils. For many rural communities in the state, reorganization had become essential if they were to provide their children with a good education. ${ }^{4}$

Industrialization and urbanization also created serious problems and pressures for Iowa's urban schools. Not only were they forced to accommodate thousands of additional children, but they were also called upon to assume new responsibilities. As the factory system supplanted home and workshop-the centers of production in agrarian societies of the past-it rendered obsolete the traditional apprenticeship system of training skilled workers. The American people characteristically turned to the public schools to fill the vacuum: to provide the industrial education that children could obtain nowhere else unless they could afford to attend a trade school.

3. Keach Johnson, "Iowa's Industrial Roots," Annals of Iowa 44 (1978), 16365, 247-49; Lawrence H. Larsen, "Urban Iowa One Hundred Years Ago," Annals of Iowa 49 (1988), 445-47.

4. IaDPI, Report (1900), 69-70; ibid. (1902), 23. 
"The industrial idea must be more intelligently and extensively embodied in our public school system," avowed President W. M. Beardshear of the Iowa State College of Agriculture and Mechanic Arts at Ames. "We have reached the period in the evolution of the American schools when one-third of the population, and more including the smaller towns, must have a more practical adaption [sic] of the common school system to meet their needs. ${ }^{15}$

IN THIS CAULDRON OF CHANGE and potential conflict, several currents of reform were bubbling to the surface of American life. Some of the stronger currents gradually flowed together to form the Progressive movement at the turn of the century. The Progressive movement was, in large measure, a response to the demands and needs of industrialism. The response began during the last half of the nineteenth century and picked up momentum as the century progressed and Iowans in common with other Americans became increasingly aware of the problems and pressures of industrial society. During these years, Iowa established institutions to provide care and treatment statewide for dependent, delinquent, and handicapped persons and created new state agencies, such as the Bureau of Labor Statistics, the Board of Health, and the Mine Inspectors, to protect and promote the public health, safety, and wellbeing. ${ }^{6}$

Progressive educators in Iowa sought to capitalize on the increasing appetite for social reform and to apply it to the reform of Iowa's public schools. In his presidential address to the Iowa State Teachers' Association (ISTA) on December 26, 1900, Principal W. O. Riddell of Des Moines West declared, "at no time in the century now closing has there been such active,

5. Proceedings of the Iowa State Teachers' Association 44 (1898), 70-71 (hereafter cited as ISTA, Proceedings). See also Oscar Handlin, Challenge to Education: Historical Perspectives on the Cultural Context (Westport, CT, 1971), 19-32, 41-43; Lawrence A. Cremin, The Transformation of the School: Progressivism in American Education, 1876-1957 (New York, 1961), 3-41; IaDPI, Report (1890), 115-17; ISTA, Proceedings 35 (1890-1891), 23-28; ibid. 40 (1894), 38-41; ibid. 44 (1898), 28-29; ibid. 51 (1905), 116, 117, 193-206.

6. John E. Briggs, History of Social Legislation in Iowa (Iowa City, 1915), 3-8, 68-143. 
such intense and enthusiastic interest in the public schools and in all public education as there is to-day." City Superintendent J. J. McConnell of Cedar Rapids agreed. "The past fifteen or twenty years mark a distinct epoch in the thinking of men on questions of education," he told the ISTA in his presidential address in 1905. "The traditional theories and forms of education have never had a slighter hold, on merely traditional grounds, upon men than they have now." The dominant theme emerging from the ferment of discussion and gradually working its way into the schools was that education "should incline more and more closely to life as life is now lived," McConnell concluded. ${ }^{7}$

Clearly, Iowans were strongly influenced by the Progressive movement and even took leading roles in promoting it. Superintendent S. H. Sheakley of Des Moines West, for example, held up John Dewey's work in the Laboratory School of the University of Chicago as "an outline of promise" for the schools of the twentieth century. Sheakley affirmed Dewey's belief that traditional schools were too isolated from social reality and should be more closely related to home, neighborhood, and community. Progressive schools provided small classes to emphasize the individuality of children, a balanced curriculum comprising domestic science, gymnastics, and manual training as well as the traditional arts and sciences, and as much freedom of action for the pupils as respect for law and order permitted. ${ }^{8}$

Laypersons joined the discussion. "Uncle Henry" Wallace, the influential editor of Wallaces' Farmer, shared Dewey's view that education must relate closely to the actuality of modern life. For Wallace, the great weakness of rural education was that

7. ISTA, Proceedings 46 (1900), 14; ibid. 51 (1905), 15.

8. Ibid. 46 (1900), 22-23. For the genesis of Progressive education and John Dewey's role as a leader of the movement, see Cremin, Transformation of the School, viii-xi, 3-176. Cremin rejects any "capsule" definition of Progressive education; it was, he says, a "pluralistic, frequently contradictory" movement that meant different things to different people $(x)$. He believes that Progressive education basically was an attempt to reform the schools in order to reform society. "It began as a many-sided protest against a restricted view of the school, but it was always more than this; for essentially it viewed education as an adjunct to politics in realizing the promise of American life" (88). 
parents could see "no immediate practical value" in the work of the schools beyond the three R's. The purposes of education, said Wallace, were to awaken the mind of the child and to develop "his native powers of observation, orderly statement, and correct reasoning." To achieve these ends, rural teachers must turn from the textbooks to the life and business of the farm; they must teach their students to observe and study life around them. "Let her interest her pupils in the things that touch the farmer's life; . . . let her show the parents by her work that she is waking up the minds of the scholars so that they ask questions not in the books concerning farm matters that the farmer cannot answer, and would like to learn for himself, and she will be the most highly appreciated person in the entire community," Wallace declared. ${ }^{9}$

Some Iowa Progressives speculated that the poor quality of rural education was one of the principal reasons for the alarming rate of migration from country to city. Claiming to represent "thoughtful people" with "a growing mistrust ... of the training in our schools," J. B. Harsh, a Creston banker and legislator, asked, "How much are our schools responsible for the general exodus from country to city?" State Superintendent Barrett remarked in 1901 that many of Iowa's towns and cities were made up largely of "retired farmers who have left the country and moved into town ... to educate their children and give them the best they can afford." 10

This tendency to link educational and social reform was characteristic of the most influential school reformer in Iowa at the turn of the century, State Superintendent Henry Sabin. A pioneer of Progressive education in Iowa, Sabin gained national recognition as a rural-school reformer, serving as chairman of the National Education Association's Committee of Twelve to Study the Condition of Rural Schools in 1896-1897. Anticipating the Country Life movement, Sabin thought that the problems of rural education reflected the general condition of rural life. Raising academic standards by means of better facilities

9. ISTA, Proceedings 40 (1894), 74-75. See also Cremin, Transformation of the School, 43-45, 82. Wallace subsequently served on Theodore Roosevelt's Commission on Country Life.

10. IaDPI, Report (1902), 33; ISTA, Proceedings 40 (1894), 69-70. 
and better teaching was only a small part of the task of improving country schools. Even more important was the development of the social mission of the rural school, which must be brought into close touch with life around it and be part of every plan seeking to better country life. "We must rely upon [the rural school's] instruction to make farm life more attractive, as well as more profitable; . . . and to prevent as far as possible the exodus of young people from the country to the city," Sabin insisted. ${ }^{11}$

The need for reform was urgent, Sabin emphasized, for farmers stood on the threshold of a new era in which they would be increasingly integrated into national and even international life. The country school must be prepared to help farmers adjust to the sweeping changes in farming and farm life that were approaching. Subjects dealing with all aspects of rural life-methods of cultivation and fertilization, the scientific breeding and feeding of livestock, forestry, horticulture, landscape gardening - "cannot long be excluded from the curriculum of the common school," Sabin declared. Books for the rural school library also ought to be selected with the economic and social life of the community in mind. There should be books on animal life and horticulture; books to show families how to beautify their homes and surroundings; and books on art, history, literature, science, and travel in order to expand the farmer's knowledge and outlook and "to make him what he is not now, 'a citizen of the world." 12

AS IOWANS AWAKENED to their need for better schools, they became aware of the importance of good teachers. "A sentiment prevails in favor of better teachers and there is a demand for the best obtainable," declared Superintendent Annie Packer of Henry County. School boards were beginning to understand the "urgent need" to employ qualified teachers and were willing

11. ISTA, Proceedings 43 (1897), 13-14, 16-17; ibid. 45 (1899), 44; Carroll Engelhardt, "Henry Sabin (1829-1918): 'The Aristocracy of Character' and Educational Leadership in Iowa," Annals of Iowa 48 (1987), 388-412. For the Country Life movement, see Cremin, Transformation of the School, 82-85; and Wayne E. Fuller, The Old Country School: The Story of Rural Education in the Middle West (Chicago, 1982), 218-21.

12. ISTA, Proceedings 45 (1899), 44-46. 
to pay higher salaries for "excellent" teachers. "We feel that at whatever sacrifice better wages must be paid if we want better schools," said Packer. School boards in other counties were reaching similar conclusions. Superintendents Charles Schell of Hancock County and Beniah Dimmitt of Wapello County reported that school districts were increasingly willing to spend more money to get better teachers: ${ }^{13}$

The growth of public understanding and support encouraged the growth of a professional spirit among teachers. Superintendent Bertha Howard of Clarke County cited the teachers' pursuit of self-improvement through professional training and home study as evidence that the schools of the county were improving. Superintendent F. E. Lark of Monona County spoke highly of the "large number of live, earnest, moral, and progressive teachers" in his county; they were willing "to devote time and money, and to sacrifice many pleasures, that they may know that their work in the school room has been well done." They overlooked no opportunity to sharpen their teaching skills, attending teachers' meetings and county institutes and reading "good books" and educational journals. ${ }^{14}$

One of the most visible signs of the growth of a professional spirit among teachers and administrators was the proliferation of professional organizations. The parent Iowa teachers' organization, the Iowa State Teachers' Association, originated in 1854 , but the great outburst of organizational energy occurred in the 1890s. Sectional teachers' associations were formed in the four quarters of the state in 1894-1895, and county, district, and township associations spread rapidly. State Superintendent Henry Sabin described 1895 as a year of educational activity "unprecedented in the history of Iowa." There were more than 1,100 education meetings in the state during the year; more teachers, school officers, and laypersons attended those meetings than ever before. Of the 99 counties in the state, 93 had county or township teachers' associations; many had both. Sabin thought that the ferment of organization

13. IaDPI, Report (1902), 302, 301, 339.

14. Ibid., 289, 321. See also ISTA, Proceedings 52 (1906), 27-45. 
and discussion in education signaled the "dawn of a new era," the coming of a "mighty revival, an educational pentecost." ${ }^{15}$

Teachers benefited socially and professionally from association meetings. Superintendent C. M. Williams stated that the meetings of the Greene County Teachers' Association gave teachers an opportunity to become acquainted, to learn new methods of teaching, and to develop a professional spirit. Much good came from the "commingling" of teachers in the yearly meetings of the Lucas County Teachers' Association, said Superintendent C. F. Goltry, as well as from the papers and discussions of professional subjects, music, model class recitations, and talks by parents. ${ }^{16}$

The teachers' meetings also stimulated public understanding and support of the schools, especially in rural areas. "Considerable progress toward a better public sentiment has been made in the rural districts by educational meetings," observed Superintendent J. E. Durkee of Buena Vista County. "As these meetings are very generally attended by parents, they have been instrumental in removing much of the prejudice and suspicion which so often exist in the rural districts against teachers and modern methods." 17

The teachers' growing desire for professional training and advancement brought about changes in methods of teacher training. Annual county normal institutes had been the principal agencies for training teachers in Iowa and other midwestern states. ${ }^{18}$ Most rural teachers, possessing only a common-school education and too poor to attend college, university, or normal

15. ISTA, Proceedings 41 (1895-1896), 64. See also, ibid. 39 (1893), 105-9; ibid. 40 (1894), 4; Edgar B. Wesley, NEA, The First Hundred Years: The Building of the Teaching Profession (New York, 1957), 342-52; and Irving H. Hart, Milestones (Des Moines, 1954) 1-12. Milestones is a history of the Iowa State Teachers' Association, 1854-1945, and its successor, the Iowa State Education Association, 1945-1954.

16. IaDPI, Report (1902), 299, 315.

17. Ibid., 285.

18. The normal institute originated in 1839 when Henry Barnard, the distinguished Connecticut educator, brought a group of young people together to teach them how to teach by means of lectures on teaching techniques and observation of classes in the Hartford schools. Barnard's initiative soon spread to New York and then to the Middle West where the institutes achieved their greatest popularity and importance. Nearly all of the North 
school, had no other opportunities for additional training. County superintendents agreed that the institutes were indispensable. "We could not get along without the annual institute gathering," observed Superintendent Charles Schell of Hancock County. ${ }^{19}$

The institutes were in a state of transition, however. Organized by the county superintendents, their aims and programs reflected the superintendents' perceptions of local needs and demands and varied from county to county. Some superintendents emphasized academic work. Others sought a mixture of academic and professional programs. But the trend was toward the professional and away from the academic. In Clinton County, Superintendent G. U. Gordon dropped the academic component and made the institute "professional and inspirational." He brought in a mixture of professional instructors from outside as well as inside Iowa in the belief that "this mingling of broad educational ideas had a tendency to release the teacher from the cocoon into which she sometimes has a tendency to weave herself." Superintendent J. C. Bennett, too, shifted the focus of the Ringgold County Institute from academic work to psychology and methods of teaching; otherwise, he said, "over ninety per cent" of the teachers in the county "would not come in touch with the educational thought outside of the county." Superintendent K. N. Knudsen organized the program of the Winnebago County Institute for the benefit of competent teachers who attended the institute "to gain inspiration." "Persons needing a review in the subject-matter should obtain that elsewhere," he said. "The institute cannot take the place of the school. ${ }^{20}$

Central states had adopted the institutes by the end of the Civil War, and many of the states sought to make the institutes more accessible in the $1870 \mathrm{~s}$ by requiring their counties to hold them. Iowa took this step in 1874. See Fuller, The Old Country School, 169; and Clarence Ray Aurner, History of Education in Iowa, 5 vols. (Iowa City, 1914-1920) 2:172.

19. IaDPI, Report (1902), 302. Fuller, The Old Country School, 169-77, thinks that the county institutes "were perhaps the most practical teacher-training programs ever devised in the nation." They were "the rural young people's colleges." They became an integral part of rural education in the Middle West in the 1880 s and 1890 s. Nearly twenty-three thousand persons attended the institutes in lowa in 1896. Aurner, History of Education in Iowa, 2:172-84.

20. IaDPI, Report (1902), 291, 331, 344. 
Some superintendents offered a county summer school as well as an institute. They realized that the institutes, which were generally held for two or three weeks in the summer, were not suitable for effective academic study: the time was too short and the weather was too hot. They also knew, however, that many teachers needed a better grasp of the subjects they were teaching. The superintendents attempted to resolve this problem by limiting the institute to pedagogical matters and setting up a separate summer school for academic purposes. "Academic work cannot be done in two weeks time, especially in hot weather," explained Superintendent S. M. Holladay, who organized a six-week summer school in Warren County in 1900. "A strictly inspirational institute of one week where the teachers meet and listen to lectures on methods, science, childstudy and kindred topics, and go away rested, energized and enthused, is much more beneficial than two weeks of hard work in hot weather where the teachers go home exhausted from the attempt to do academic work in so short a time."21

Beginning teachers welcomed the county summer schools as an important expansion of the local educational opportunities available to them. Attendance at the Butler County summer school, which was designed to help teachers prepare for the certification examinations, averaged about sixty-eight persons per year for three years, 1898-1900. This heavy attendance helped to relieve the county's shortage of well-qualified teachers. Superintendents Elsie Perry of Howard County, S. M. Holladay of Warren County, and Inez Kelso of Wayne County were also pleased with the teachers' response to the summer schools they organized in 1900 and 1901. Many of the Warren County teachers told Holladay they hoped the summer school would become a fixture in the county's educational program. ${ }^{22}$

Teachers seeking more advanced work than that provided by the county institutes and summer schools turned increasingly to Iowa's colleges, universities, and normal schools. The summer schools of the state university and state normal school "have been largely attended by many of the most progressive superintendents, principals, and teachers," who could not

21. Ibid., 340.

22. Ibid., 286, 340, 342. 
attend at other times, State Superintendent Barrett reported in 1901. He recommended that appropriations for the summer schools, which the three state institutions of higher learning were just beginning to offer, be made permanent. Superintendent G. U. Gordon of Clinton County attributed the growing number of teachers attending Iowa State Normal School to the realization by school boards as well as teachers that the school provided "excellent" professional training; teachers who attended the school had no difficulty getting the best position available. Thus, observed Superintendent Mary Hughes of Washington County, "The demand for a higher standard of scholarship is being met by attendance at the state normal and other schools and colleges." 23

CLOSELY ASSOCIATED with the growing public understanding of the importance of good teaching was the growing popular realization of the need for better facilities. People were becoming aware of the necessity of proper heating, lighting, sanitation, and ventilation in buildings and the value of beautifying buildings and grounds. "As old schoolhouses are being replaced with new," reported State Superintendent J. B. Knoepfler in 1893, "there is a commendable ambition to put up a better class of buildings, as to convenience, comfort and appearance." 24

Many school districts, unable to employ an architect, turned to the State Department of Public Instruction for architectural advice and information. The state superintendents could not furnish blueprints, but they responded to the inquiries of local school officials by publishing photographs of new schoolhouses in their biennial reports, including floor plans and estimated costs whenever possible. State Superintendent Henry Sabin, for example, made a strenuous effort to collect a large number of cuts of schoolhouses recently built in Iowa for his 1895 report, including an architect's drawing of a model one-room schoolhouse complete with floor plan and specifications supplied by the State Board of Health. "We think no

23. Ibid., 16, 292, 341

24. Ibid. (1894), 165. 
feature of this report will prove of greater interest and usefulness than this," Sabin observed. ${ }^{25}$

Following up Sabin's initiative, his successor, Richard Barrett, included a chapter titled "School Architecture" in his report for the biennium, 1899-1901. Comprising thirty-seven pages of cuts, the chapter was the most ambitious project yet undertaken by the state superintendents to modernize school buildings in Iowa. The chapter consisted largely of architect's drawings of school buildings, with floor plans, specifications, and costs, but it also included photographs of new schoolhouses with a few interior views of offices, assembly halls, and classrooms showing students at work in manual training and mechanical drawing classes. The collection presented a variety of sizes and styles of school architecture, ranging from one- and two-room frame or brick rural and village schoolhouses to two-story brick buildings in cities and towns. Costs of the structures ranged from $\$ 590$ for a small frame building in rural Pocahontas County to $\$ 32,000$ for a two-story brick building in Odebolt. The new buildings, Barrett commented, illustrated the improving school architecture in Iowa. "Each year the beautiful is given more prominence in the educational world," wrote Barrett. School boards in rural communities as well as those in cities and towns were realizing the need to consider appearance as well as cost and utility in planning the construction of new buildings. ${ }^{26}$

Improvements in rural schoolhouses were necessarily more modest than those in urban buildings, but they were substantial nonetheless. "Teachers and school officers are exercising themselves to improve school houses, outbuildings and grounds," observed Superintendent H. L. Adams of Fayette County. Thirteen schoolhouses were built in Madison County during the biennium, 1899-1901. "With few exceptions," reported Superintendent H. D. Smith, "the school-houses are kept in good condition, neat, tidy, and home-like, and are supplied with sufficient apparatus." Superintendent F. E. Lark of Monona County was also pleased by the attractive environment of many of the rural schools he visited. "I have noticed a

25. Ibid. (1896), 196-204.

26. Ibid. (1902), 135-73. 
great change in the decoration of the school room in the past few years," Lark reported. "Our teachers are realizing the silent influence of plant and flower, of mottoes and pictures, of clean floors and neat surroundings on the thought, life, and character of the child." Many of the school rooms that Lark visited were "the very picture of neatness and order"; stoves were carefully blacked, floors were clean, windows were framed by white sash curtains, and walls were tastefully decorated with pictures, creating "an air of cheer and comfort which means much to the future of the child. ${ }^{27}$

While state superintendents were encouraging local authorities to build modern schoolhouses, they were also busily engaged in promoting the establishment of rural-school libraries. Few rural schools had libraries at the turn of the century. Here, as in so many other areas, State Superintendent Henry Sabin provided early leadership, warning in 1895 that there was a "pressing need" to establish school libraries. Directing the reading of children ought to be "no small part" of the teacher's task, said Sabin. "To know the value of books, and how to use them, is itself an education." Many schools did not even possess a dictionary, however. Few were well supplied with reference books. "There are thousands of teachers who have no resources beyond the text-book in their hands," reported Sabin. "The teacher who has not access to books of reference, to histories, geographies, travels and biographies, is shorn of half his teaching power." ${ }^{28}$

Growing public interest in school libraries led the General Assembly in 1898 to direct State Superintendent Barrett to investigate the "practicability and desirability" of establishing free libraries in Iowa's public schools. Surveying school libraries in 1899, Barrett found that existing conditions varied widely from county to county, ranging from counties such as Cherokee, where all of the 141 districts in the county had school libraries with a total of 7,000 books, to counties such as Monroe, whose 97 districts included only one school library with an unreported number of volumes. Of the 134 districts in Ringgold County, 36 claimed to have school libraries, but some

27. Ibid., 298, 317, 321.

28. Ibid. (1896), 173-74. 
of them possessed no more than four or five books. Union County with 112 districts listed 20 school libraries and a total of 2,820 volumes, but County Superintendent Charles Peters said that there was only one "good" school library in the county. ${ }^{29}$

Barrett also surveyed other state superintendents. He learned that the states differed considerably in their methods of funding school libraries. They were virtually unanimous, however, in agreeing on the necessity of libraries. Of the various methods used to pay for the organization and support of school libraries, Barrett thought that the best approach was to direct school boards to set aside a certain percentage of their portion of the state school fund to purchase library books. ${ }^{30}$

Adopting the substance of Barrett's recommendation in 1900, the General Assembly enacted a law requiring the directors of school townships and rural independent districts to create a library fund by withholding from the district's share of the state school fund not less than five cents and not more than fifteen cents for each person of school age living in the district. The money was to be used to buy books from lists prepared by the state board of educational examiners. Officers of the school board or persons designated by them were to act as librarians, but the books were to be placed in the schools when they were in session, and teachers were to be responsible for their care and protection, so in effect, teachers were to be the librarians. ${ }^{31}$

The library law took effect on July 4, 1900. Public reaction to the law was mixed, ranging from enthusiasm to skepticism to hostility. In Plymouth County all of the school townships and rural independent districts complied with the law, many school boards levied the maximum amount permitted by the law, and teachers were active in raising money to augment public funds. Elsewhere, parents joined teachers in raising money to support school libraries. Superintendents in Buena Vista, Cerro Gordo, and Palo Alto counties reported that entertainments, "sociables," and private donations raised significant amounts of money to buy books, encyclopedias, and bookcases. ${ }^{32}$

29. Ibid. (1900), 91-92; ibid. (1902), 331, 338.

30. Ibid. (1900), 81-90.

31. 1900 Laws of Iowa, 83.

32. IaDPI, Report (1902), 327, 285, 289, 326. 
Not all school boards welcomed the library law, however. There was "considerable opposition" in Ringgold County, where Superintendent J. C. Bennett found it necessary to make personal calls on directors of school boards in order to persuade them "to take any steps at all" to implement the law. Opposition was also "very stubborn" in some parts of Keokuk County, where people regarded libraries as a fad. Most of the districts in the county complied with the law, "secretly hoping that the books would prove useless and the entire scheme a nuisance," declared Superintendent W. H. Gemmill. There was "more or less" opposition to the library law in a number of school districts in Lucas County, where critics questioned the "usefulness" of school libraries, fearing "the early destruction of the books by careless and unscrupulous pupils." ${ }^{\text {"3 }}$

A year's experience tempered popular distrust of the library law. Initial prejudice against the law in rural communities of Butler County had been "largely overcome," reported Superintendent H. B. Akin in 1901; school boards no longer needed "much urging" to carry out the law. Implementation of the law in Keokuk County turned out to be even more successful than its most ardent friends had hoped; with only a few exceptions, every rural school in the county had a library by the end of the 1900-1901 school year, although some of them were very small. Fears that the pupils of Lucas County would destroy library books proved to be groundless. "So far this year [19011902], orders for books have been more liberal, and the measure bids fair to meet with general favor and success," concluded Superintendent Goltry. ${ }^{34}$

Some of the initiative for establishing and improving ruralschool libraries came from public-spirited private citizens. One of the leaders was George W. Schee, a prosperous Primghar attorney, businessman, politician, and philanthropist. He launched the library movement in $\mathrm{O}^{\prime}$ Brien County by offering cash prizes to the five rural schools that raised the most money to buy books for their libraries. He also contributed one hundred dollars annually to organize a library for O'Brien County teachers. His challenge led to significant improvements not

33. Ibid., 331, 310, 315.

34. Ibid., 286, 310, 315-16. 
only in O'Brien County, but in Mitchell, Osceola, and Sioux counties, where improvements in school libraries were due largely to Schee's philanthropy and inspiration..$^{35}$

The introduction of school libraries enlarged and enriched the educational opportunities of rural children, adding a new dimension to rural education in Iowa. "No one thing has done more for the educational advancement of our county than has the library movement," declared Superintendent Ella Daniel of $\mathrm{O}^{\prime}$ Brien County. More restrained in her assessment but positive nevertheless, Superintendent Elsie Perry characterized the libraries in Howard County schools as a "real success wherever competent teachers have charge of them." Superintendent Durkee of Buena Vista County predicted that since the libraries were open to all residents of the school districts as well as teachers and pupils, they would have an "elevating influence" on the entire community. ${ }^{36}$

THE COMBINATION of professional leadership and grassroots support that sparked the library movement also proved to be effective in dealing with yet another weakness of rural education in Iowa: the haphazard nature of many rural-school programs. "The work done in many of the country schools is equal to that of the best schools in the state, but as a whole it is too fragmentary, too unsettled, too aimless, to accomplish all we may rightfully expect of it," State Superintendent Henry Sabin observed in 1891. What was needed, said Sabin, was enough system to "unify, direct, control, and stimulate" the work of the rural schools without impeding the freedom and individuality of teachers and pupils that had been the traditional strength of rural education. ${ }^{37}$

The work of numerous country schools was disorganized because those immediately responsible for their programsteachers, school boards, and county superintendents-were

35. Ibid. (1902), 319, 322-24, 334; J. L. E. Peck, O. H. Montzheimer, and William J. Miller, Past and Present of O'Brien and Osceola Counties, Iowa, 2 vols. (Indianapolis, 1914), 1:196, 268; D. A. W. Perkins, History of O'Brien County, Iowa: From Its Organization to the Present Time (Sioux Falls, 1897), 399.

36. laDPI, Report (1902), 323, 304, 285.

37. Ibid. (1892), 38. 
unable or unwilling to exercise effective leadership. The subjects to be taught, the order in which they were taken up, and the amount of time they were given were left to the desires of parents and pupils and the discretion of the teachers, who were often inexperienced, untrained, and hired for only one or two terms. The problems of rural teachers frequently were compounded by their isolation: there was no one to whom they could turn for professional help. Directors of local school boards, who were responsible for the management and operation of schools, not infrequently were indifferent or incompetent. "As a rule the best citizens will not serve as a school director; this often leaves the matter of education in the hands of, sometimes well meaning, but incapable men," observed Superintendent Anna White of Jefferson County. County superintendents, whose many duties included supervision of rural schools, frequently were inexperienced themselves, since they were subject to reelection every two years and the rate of turnover was high; and even the most conscientious county superintendents were able to visit rural schools no more than two or three times a year at most. ${ }^{38}$

State Superintendent Henry Sabin initiated the movement to standardize and upgrade the work of rural schools. Responding to "urgent solicitations from many parts of the state," Sabin published a handbook for Iowa schools in 1890. The handbook included provisions of school law that directors and teachers needed to know, synopses of state and national government, and a course of study prepared to meet the needs of rural schools. The original printing was soon exhausted, so in. 1891 and 1893 the Department of Public Instruction printed additional copies, which were sent to county superintendents for distribution to rural schools. County superintendents welcomed the handbook and promoted its adoption and use, leading Sabin and his successors to publish revised editions in 1895 , 1900 , and $1906 .^{39}$

38. Ibid. (1902), 307. See also ibid. (1892), 36; ibid. (1894), 24, 201; ibid. (1902), 291, 340-41.

39. Ibid. (1892), 36-38; ibid. (1894), 24; ibid. (1896), 74; ibid. (1902), 325; IaDPI, Hand-Book for lowa Schools (Des Moines, 1906), preface. 
The most important feature of the handbook was the course of study, which was designed to provide an orderly, systematic, uniform curriculum for the common schools of rural Iowa. It "received almost universal adoption . . . with the most beneficial results," the state department announced in 1894. The handbook was, in effect, a what-to-do and how-to-do-it manual; it recommended a list of subjects for each of the eight years of the common school and suggested detailed methods and procedures to be used in teaching the course. It outlined what to teach and how to teach it subject by subject and month by month during each of the eight months of the school year. It also recommended supplementary books, readings, songs, and games. ${ }^{40}$

The handbook filled a void in schools that had no curriculum. Noting that rural school boards were "slow to adopt any course of study," Superintendent Anna White of Jefferson County stated that nearly all of the teachers in the county were using the state department's course of study in schools where no other course was provided. The handbook offered a balanced treatment of basic subjects and skills to replace the haphazard approach that prevailed in many country schools. Superintendent W. T. Dick of Van Buren County reported that all of the rural and village schools in the county used the course of study laid out in the handbook. "The result is that the pupils of all the rural schools follow a systematic course, and do not as formerly leave school with no knowledge of grammar, geography, etc., but study all the branches in the course." Commenting on the effectiveness of the course of study in 1895, State Superintendent Sabin reported, "We have been gratified to hear city superintendents in different sections of the state say that pupils coming to their schools from the country are well fitted in the branches they have studied. Such instances are sufficiently numerous to show that country schools can do good work and that in many counties they are doing good work." ${ }^{\text {41 }}$

The growth of uniformity in rural-school programs and procedures had other advantages. It facilitated the transfer of

40. IaDPI, Report (1894), 186-87; IaDPI, Hand-Book for Iowa Schools (Des Moines, 1900), preface, 5-50; ibid. (Des Moines, 1906), preface, 5-232.

41. IaDPI, Report (1902), 307, 338; ibid. (1896), 146. 
children whose parents moved from one school district to another. It also enabled county superintendents to give examinations to rural children finishing common school and to award diplomas to those who were successful. This had been one of the objectives of the state department all along. Sabin believed that a common course of study would draw schools closer together and that the prospect of receiving "deserved recognition" when they completed the course would stimulate children to continue in school. In issuing a revised edition of the handbook in 1900, State Superintendent Barrett pointed out that fully one-half of the children of Iowa received no formal education beyond that furnished by the common schools. He urged county superintendents to offer students an incentive to finish common school by giving a county examination to those who completed the course and a common school diploma to those who passed the examination. ${ }^{42}$

A number of county superintendents heeded Barrett's urging. In Mitchell County, for example, Superintendent Jay Lapham presented more than forty common school diplomas to rural children who completed the state department's curriculum in 1900. Describing the diploma as the capstone of the state's course of study, which was "well followed throughout the county," Lapham reported that the graduation exercises aroused "deep" popular interest. "The common school diploma is a strong factor in giving system and effectiveness to our rural schools," said Lapham. In Page County, Superintendent H. E. Deater also found such graduation ceremonies to be "an effective means of arousing a better educational sentiment among the people," adding, "They have proved to be educational revivals in this county. ${ }^{.43}$

The prospect of winning a common school diploma stimulated the awakening desire of rural parents and children for a better education. The "prevailing sentiment" of the people of Benton County, reported Superintendent A. K. Rife, was that rural children ought to finish common school, take the county examination, and earn a diploma. A common school diploma was not only important in its own right, but it also entitled

42. Ibid. (1892), 37-38; Hand-Book for Iowa Schools (1900), 9-10.

43. IaDPI, Report (1902), 319-20, 325. 
students to enter high school. A growing number of rural children were taking advantage of the opportunity. Superintendent O. J. McManus noted that Pottawattamie County diplomas were a "passport" to any high school in the county and that the rural schools and high schools of the county were more closely linked than formerly. "The system is working nicely, and will be the means of pointing many of our boys and girls to something beyond the rural school," predicted McManus. ${ }^{44}$

THE GROWTH of public interest in the schools directed public attention to weaknesses in their organization and operation. The basic units in the structure of Iowa's public school system were the district township, which was divided into subdistricts, and the independent district. There were 1,187 district townships and 3,686 independent districts in Iowa in 1900; the townships included 9,423 subdistricts, making a total of 14,296 largely autonomous, self-governing school units. Critics complained that Iowa had more schools than it needed; that the fragmentation of the state into independent districts and township subdistricts was expensive, inefficient, and wasteful; that many of the rural independent districts and subdistricts were too small, too poor, and too sparsely populated to support good schools. In 1899, 2,577 rural schools in Iowa had an average daily attendance of fewer than ten children. "Small schools are to be deplored," declared State Superintendent Barrett. "It is doubtful if they give value received for 50 per cent of the money expended to maintain them." 45

Many county superintendents agreed with Barrett. They had come to believe that consolidation of small districts and public transportation of their pupils to central schools were the keys to the future of rural education in Iowa. Superintendent S. M. Holladay of Warren County, for example, thought that the characteristic problems of rural schools-unqualified, poorly paid teachers, irregular attendance, pupil dropouts, unkempt buildings and grounds, inadequate equipment-were likely to continue until consolidation was achieved. County superintendents such as E. D. Brown of Sioux County, an apos-

44. Ibid., 282, 329.

45. Ibid., 23, 463 . 
tle of the "gospel of consolidation and transportation," promoted the discussion of consolidation at meetings of parents, teachers, and school officers. Interested laypersons took up the question, and it attracted increasing public attention in a number of counties. There was a "general feeling" in Greene County, said Superintendent C. M. Williams, that the money expended on education could be spent more effectively by consolidating some of the districts. Consolidation also seemed to be "gaining ground" in Mitchell, Van Buren, and Webster counties, although it was "very hard" to overcome the "mental inertia" of the mass of the people. ${ }^{46}$

The consolidation of school districts had been advocated by leading Iowa educators almost from the state's inception. As it attracted increasing popular attention, it began its long and troubled career as one of Iowa's most controversial questions. Gradually, however, the traditional one-room, one-teacher rural school with its pot-bellied stove, outdoor pump, and privy, serving four sections of a township within a two-mile radius, began to give way to a central schoolhouse built of brick and equipped with central heating and indoor plumbing. ${ }^{47}$

THE EFFORTS of reformers to modernize elementary and secondary education in Iowa came under the leadership of the Iowa State Teachers' Association (ISTA), the oldest, biggest, and most influential organization of professional educators in the state. Formed in 1854 "to promote the educational interests of the state, improve teachers, and elevate the profession of

46. Ibid., 340-41, 335, 299, 319, 338-39, 343. For a spirited defense of the independent rural district and the one-room school, see Fuller, The Old Country School, 42-58 and passim. Fuller views the struggle over consolidation as a contest between professional educators, who had already gained control of urban schools and wanted "to centralize, bureaucratize, and systematize" rural education and "individualistic and democratic" farmers who insisted on retaining the independent district system and running the schools as they saw fit (106). Fuller's sympathies are with the farmers; he thinks that it would be difficult to exaggerate the contribution of the small school districts to the education of rural children and to the social and political life of farm communities throughout the Middle West in the nineteenth and early twentieth centuries (45).

47. See, for example, IaDPI, Report (1900), 71-79; ibid. (1904), 225; ibid. (1906), 20-23;' ISTA, Proceedings 48 (1902-1903), 49-50; Hart, Milestones, $162,167-68$. 
teaching," the ISTA became public education's principal voice in Iowa in the 1890s. In his presidential address in 1895, future State Superintendent Richard Barrett told the ISTA that its recommendations had been "so thoughtful" that "not a single great change has been made in the school law [of Iowa] that has not first been subjected to the most careful investigation by this body." "Upon examination it will be found that the teachers' normal institute, the graded school system, the high school, the state normal school, the granting of state certificates and diplomas, the establishment of the chair of pedagogy in connection with the state university, and uniformity of text-books, have been approved by this association, or in fact, originated in the association," Barrett declared. ${ }^{48}$

At the turn of the century, teaching had not.yet become a profession in Iowa or the United States, but it was moving in that direction. Teachers were beginning to develop goals and standards and a sense of identity. They were starting to seek advanced training, join professional organizations and attend professional meetings, participate in community affairs such as the drives to raise money for school libraries, and reach out to parents for cooperation and understanding. But perhaps the best evidence for the professionalization of Iowa teachers was the enhanced status and influence of the ISTA. ${ }^{49}$

The association grew rapidly in membership, political and professional consciousness, and social outlook at the turn of the century. Attendance at the association's yearly meetings nearly quadrupled, rising from 1,000 in 1897 to 3,900 in 1910 . Stating that the organization represented more than 20,000 teachers and 728,000 pupils, State Superintendent Barrett described the association in 1903 as "the largest voluntary organization for the general improvement of mankind" in Iowa. As the association grew, its leaders, realizing its potential power, sought to mobilize the rank and file for political action. President Homer $\mathrm{H}$. Seerley of Iowa State Normal School told the association in 1894 that it had passed from youth to maturity and must act accordingly. The time had come to substitute action for talk so

48. ISTA, Proceedings 39 (1893), 105-9; ibid. 41 (1895-1896), 26; Aurner, History of Education in lowa, 2:190-244; Hart, Milestones, 1-12.

49. See Wesley, NEA, 342-52; Hart, Milestones, 1-12. 
that the association could influence "the forces that govern and legislate for this age and this commonwealth." The association reached into every school district in the state; it could become a "mighty force" if it would only "centralize its power and have some unanimity of purpose.

State Superintendent Sabin agreed that the association must take the lead in promoting educational reform. The state department was ready to help, he said, but it was burdened with administrative details. Besides, the drive for needed legislation must come from a source closer to the people than the state department. The state teachers' association, Sabin noted, represented "every city and town; we reach every hamlet and district; we are in close touch with the people. We can appeal to high heaven for the rectitude of our intentions and for the justice of our cause, the welfare of 500,000 children in our schools." The association must prepare needed legislation, place its bills in the hands of friendly representatives and senators for sponsorship, and shepherd the bills through every step of the legislative process from the committee room to the governor's desk. ${ }^{51}$

The association's legislative program took form gradually, growing out of reports and resolutions adopted at the association's annual meetings. In the 1890 s the association focused on

50. Aurner, History of Education in Iowa, 2:237-38, 241, 243; ISTA, Proceedings 40 (1894), 13; ibid. 48 (1902-1903), 47.

51. ISTA, Proceedings 41 (1895-1896), 69; ibid. 40 (1894), 65-66. Seerley and Sabin had good reason to emphasize the association's need for unity. Reflecting the increasing specialization of modern education, the association tended to divide into specialized groups as it grew to become a "federated institution" in Aurner's words. In 1899, for example, the association included the College and University Department, the County Superintendents' Department, the Department of Normal and Secondary Instruction, the Elementary and Graded Department, the City Superintendents' and Principals' Section, the School Directors' Section, the Primary Section, the Reading and Physical Training Section, the Music Section, the Penmanship and Drawing Section, and the Kindergarten Section. City Superintendent A. W. Merrill of Waverly complained that the association could hardly be considered one body. "It is little but a federation of departments and sections, and many of its members do not recognize its annual meeting except as a place and time to compare notes with fellow workers in their own special line," Merrill observed. ISTA, Proceedings 45 (1899), 132 and passim; Aurner, History of Education in Iowa, 2:209-229. 
professional problems, particularly the shortage of qualified teachers which was considered to be the greatest weakness of the state's public school system. In 1893, for example, the association emphasized Iowa's need for a better teacher-training system, calling on the General Assembly to support the state normal school more generously, to establish "at least" two additional state normal schools, and to place the "pedagogical department" of the state university on an "equal footing" with the university's other departments. The association reiterated its demand for more normal schools two years later, asserting that the need was so urgent that the General Assembly ought to act at once to provide training programs for the fifteen thousand "inexperienced and poorly qualified young persons" who were expected to descend on the rural and village schools of the state in the next two years. In addition, the association urged the General Assembly to abolish rural independent school districts and subdistricts and to make the civil township the basic unit of rural school organization. ${ }^{52}$

The association broadened its agenda and outlook in 1899, turning to the social context of education, to the relationship between social conditions and the problems of the schools. That year a comprehensive report by an association committee addressed the question, "What Shall be Done with Incorrigible and Neglected Children?" Although the ISTA had worried about juvenile delinquency almost from the association's birth, having called on the General Assembly to establish a juvenile reformatory as early as 1858 , this report represented a landmark in the evolution of the association's thinking. The report acknowledged that juvenile delinquency was a more serious problem in the cities than in the country, but warned that "nearly every rural community, even on the prairies of Iowa, has its contingent of young men and women who are going headlong into dissipation, vice, and crime." Children were not naturally incorrigible; they became so because of poverty, the loosening of family ties, parental neglect, and vicious social environments. "Under present conditions, in spite of parents, schools and churches, many children are truants, loafers, ciga-

52. ISTA, Proceedings 39 (1893), 5-9; ibid. 41 (1895-1896), 5-6, 16, 19-20, $107,112,137$. 
rette smokers and petty gamblers," the report stated. "Precocious sexual depravity, stimulated by social customs, impure literature, and vicious associations, is ruining thousands of promising youth. ${ }^{53}$

To remedy these evils, the association called for a greater sense of parental responsibility and a sweeping program of educational and social reform. Schools must emphasize subjects that strengthened character-the humanities, manual training, and gymnastics were the subjects "richest in moral suggestiveness," the association believed-and demand higher standards of character and culture of their teachers. Educational opportunity ought to be enlarged by establishing wellequipped kindergartens in all Iowa cities and towns and by setting up public or private polytechnical schools. Cities must control drunkenness, gambling, pornography, prostitution, and the corruption of public officials. The state ought to regulate child labor, require children to attend school, and institute a comprehensive program to provide for the care and training of neglected and incorrigible children. Such a program ought to include a systematic plan for placement in foster homes, institutional care for orphans and children who were "grossly neglected," a network of industrial boarding schools for youthful truants and vagabonds, and a prison reformatory for youthful criminals of each sex..$^{54}$

The rapid growth of industrialism compelled the ISTA to expand its professional as well as its social outlook. Reflecting current trends in American education, the ISTA gradually formulated a legislative program to promote consolidation, centralization, professionalization, and standardization. Beginning in 1902 and culminating in 1913, the General Assembly, responding to proposals by the ISTA and allied groups, enacted a series of laws that reorganized and modernized elementary and secondary education in Iowa. These laws required children to attend school; prohibited child labor; professionalized and strengthened state and county departments of education; increased state control over the training, examination, and certification of teachers; mandated the teaching of elementary

53. Ibid. 45 (1899), 14.

54. Ibid., 15. 
agriculture, domestic science, and manual training in all public schools; inaugurated a policy of state aid to improve the education of rural school teachers and to encourage industrial and vocational education in consolidated schools; and established a scale of minimum salaries for teachers. ${ }^{55}$

THE ESSENTIAL PARTS of an educational reform movement-professional organization and leadership, growing public understanding and support, a program and philosophywere present in Iowa by 1900 . Leading Iowa educators and laypersons were well aware that they were entering a new era, an age of mass education that would require major changes in outlook, organization, and program. The adjustments already initiated-the broadening and diversification of programs, the modernization of buildings and grounds, the development of libraries, the standardization of curricula, the beginning of consolidation-demonstrated that the public was receptive to change. The growth of the ISTA in membership, social awareness, and political sophistication offered a nucleus of professional organization and leadership. The growing collaboration of lay and professional educational reformers in response to the quickening pace of industrialism played an important part in the Progressive effort to modernize the economic, social, and political life of Iowa.

55. 1902 Laws of Iowa, 71-72, 78-80; ibid., 1906, 71-73, 87-91; ibid., 1911, 148-49, 158-61, 163; ibid., 1913, 88-90, 93-95, 246-48, 261-63, 266-69, 272; IaDPI, Report (1904), lii-lix; ibid. (1907), 20-21, 26-31; ISTA, Proceedings 48 (1902-1903), 9, 47-49, 97-99, 118-19; ibid. 49 (1903), 134-37, 16871; ibid. 52 (1906), 6-7; Aurner, History of Education in Iowa, 1:106-7, 112, 114, 122, 2:192-94, 213-14, 219; Carroll Engelhardt, "Compulsory Education in Iowa, 1872-1919," Annals of Iowa 49 (1987), 58-76; Hart, Milestones, $62-65,148,156-59,163-66$. 
Copyright of Annals of Iowa is the property of State of Iowa, by \& through the State Historical Society of Iowa and its content may not be copied or emailed to multiple sites or posted to a listserv without the copyright holder's express written permission. However, users may print, download, or email articles for individual use. 